\title{
AS NARRATIVAS EM TENSÃO EM DOIS, DE OSCAR NAKASATO
}

\author{
THE STRESS OF NARRATIVES IN DOIS, BY OSCAR NAKASATO
}

DOI 10.20873/uft2179-3948.2021v12n2p67-83

\section{Pedro Francisco dos Reis $^{1}$}

Resumo: O presente artigo tem como objeto de análise o romance Dois (2017), de Oscar Nakasato. O livro é narrado em primeira pessoa por dois irmãos com experiências de vida bastante diferentes. Enquanto um participou ativamente das ações anti repressão no período da Ditadura Civil-Militar brasileira, o outro se punha contrário aos movimentos ditos subversivos. Propõe-se verificar suas visões destoantes. Além disso, será feita uma breve leitura das reverberações das diferentes visões como partes constituintes de um processo de "astigmatismo histórico", como explanado por Edson Telles e Vladimir Safatle (2010), inscrito no atual cenário brasileiro.

Palavras-chave: Dois; literatura contemporânea; ditatura militar; anistia

Abstract: This article aims at analyzing the novel Dois (2017), by Oscar Nakasato. It is narrated in first person by two brothers who have had entirely distinct life experiences. One has actively participated in anti-repression practices during the Civil-Military Dictatorship in Brazil, whereas the other one has been opposed to the so-called subversive movements. The article intends to verify their opposing perspectives. Besides that, a brief correlation will be made of their views and the repercussions they bring to a current scenario in Brazil explained as "historical astigmatism", by Edson Telles and Vladmir Safatle (2010).

Key-words: Dois; contemporary literature, military dictatorship; amnesty

\section{Introdução}

É abundante o que se tem escrito acerca da Ditadura Civil-Militar no contexto da literatura contemporânea brasileira. Em A literatura como arquivo da ditadura brasileira (2017), Eurídice Figueiredo estipulou um grande corpus de textos literários provocados pelo regime e acredita que "só a literatura é capaz de recriar o ambiente vivido por personagens afetados diretamente pela arbitrariedade, pela tortura, pela humilhação" $(2017$, p. 43) - marcas

\footnotetext{
${ }^{1}$ Mestrando em Estudo Literários Aplicados pelo Programa de pós-graduação em Letras da Universidade Federal do Rio Grande do Sul (UFRGS). E-mail: pedro.freis26@ gmail.com. ORCID: https://orcid.org/0000-0001-7025$811 \mathrm{X}$.
} 
estas que foram constitutivas do aparato ditatorial no país. Figueiredo (2017, p. 44) acredita que "a literatura, pelo viés da subjetividade, mostra resíduos de experiências fraturadas pela violência do vivido". Neste sentido, a organização de um arquivo literário da ditadura parece ser uma forma interessante de resistência e combate perante uma sensação de esquecimento que paira na atmosfera brasileira. Similarmente ao que estipulou a autora, na Apresentação do livro O que resta da ditadura: a exceção brasileira (2010), Edson Telles e Vladmir Safatle (2010, p. 9) percebem que a sociedade brasileira parece "ser vítima de um certo astigmatismo histórico" no que diz respeito à lembrança do que aconteceu durante os anos de controle ditatorial. Nota-se, então, que o esquecimento deste passado recente, característico do caso brasileiro, tem permitido a rememoração e a reprodução de discursos, a aceitação de práticas e, até mesmo, a permissão de um sentimento de nostalgia em relação às formas de controle exercidas pelo estado brasileiro - sob a justificativa da exceção - contra aqueles que se opunham ao sistema então vigente. Deste modo, estipulam Telles e Safatle (2010, p. 9):

[...] faz-se necessário mostrar, àqueles que preferem não ver, a maneira insidiosa que a ditadura militar brasileira encontrou de não passar, de permanecer em nossa estrutura jurídica, em nossas práticas políticas, em nossa violência cotidiana, em nossos traumas sociais que se fazem sentir mesmo depois de reconciliações extorquidas.

Gínia Maria Gomes (2020), em “O Romance Brasileiro: as ruínas de um passado traumático", na coletânea de ensaios Narrativas Brasileiras Contemporâneas: Memórias da Repressão, pensa o presente período no espaço literário como uma resposta a questões não resolvidas no pensamento coletivo brasileiro. Gomes (2020, p. 9) escreve que "o romance do século XXI, notadamente depois de 2014, tem um número expressivo de títulos que tematizam a ditadura brasileira", observando como significativo o processo de anistia "que se estendeu aos torturadores não permitiu um acerto de contas, uma vez que os responsáveis por crimes hediondos não foram punidos" (GOMES, 2020, p. 7).

É dentro deste período que se encaixa o romance Dois (2017), do autor paranaense Oscar Nakasato, que será abordado neste artigo. Nakasato ganhou notoriedade com o livro Nihonjin (2011), vencedor do prêmio Jabuti na categoria romance no ano de 2012. Dois é seu segundo romance. No livro, Nakasato cria uma narrativa de memórias compartilhadas através de dois narradores: são irmãos que, no presente da obra, têm mais de sessenta e cinco anos e que vivenciaram o período da Ditadura Civil-Militar de maneiras largamente distintas. Dois é organizado em curtas passagens que não distribuem simetricamente as vozes narrativas - há 
compêndios, em sequência, de duas ou três, por vezes até mais, destas passagens que são atribuídas a uma mesma voz, ora Zé Paulo ora Zé Eduardo.

O presente artigo analisará a perspectivas dos dois narradores-personagens sobre o período ditatorial brasileiro a partir dos discursos apresentados na obra. Esses narradores têm sete anos de diferença de idade: o mais velho, Zé Paulo, e o irmão mais novo, Zé Eduardo. A primeira seção de análise terá como foco principal a perspectiva contrária às práticas de resistência à ditadura pela voz de Zé Paulo. Já a segunda seção, tratará majoritariamente da perspectiva e da experiência de Zé Eduardo, membro de ações de combate à repressão do período de governo militar. As duas visões, em contraposição uma à outra, são percebidas como a montagem de um cenário ainda bastante evidente no presente do país. Nakasato, em Dois, apresenta o choque e o estranhamento de personagens que são forçados a coexistência ainda que tenham visões ideológicas e políticas extremamente discordantes.

\section{1 “Zé Eduardo largou a mãe chorando pra se aventurar lá com aqueles desordeiros"}

As verdades inquestionáveis permeiam a narrativa da Zé Paulo. Ele, primogênito, condição que aceita "sem questionamentos, quase feliz" (NAKASATO, 2017, p. 47), procurava na figura do pai um espelho que lhe servisse de guia. O pai era "um homem reto, traçou estradas retas para os filhos percorrerem, principalmente Zé Paulo" (NAKASATO, 2017, p. 47). Nessa família de Josés - o pai e os três filhos foram assim batizados -, "Zé Paulo era a prova primeira de imortalidade [...] a gravidez foi anunciada, sorriram: continuamos" (NAKASATO, 2017, p. 47). Desde então, nota-se que há uma carga de expectativas que foram lançadas sobre o filho mais velho. As mesmas não observadas no mais novo. O constante chamamento da figura paterna como exemplo, elucida que tal espelhamento atravessa o imaginário de Zé Paulo a todo o tempo e está refletido no seu posicionamento e nas suas ações ao longo de Dois.

Desta forma, Zé Paulo procura montar uma vida semelhante àquela objetivada pelo pai. Sua rotina resumia-se às tarefas cotidianas e seus objetivos de vida fixavam-se em noções ordinárias. Esperava o normal: sabia que estudaria o necessário para conseguir um bom emprego, que iria se casar, que teria filhos, que construiria um lar, uma família. Sabia que trabalharia desde cedo da manhã até o fim do dia e estava resignado a tal realidade. Com o pai, aprendera que "o trabalho torna o homem digno" e "que a gente precisa cumprir regras" (NAKASATO, 2017, p. 21). O estrito cumprimento de regras lhe confere noções claras do que é certo e do que é errado. À sua maneira de tocar a vida, ele confere estatuto de certo, de verdade. Já as vivências que se distinguem da sua realidade, ele vê como errado. 
Como narrador, Zé Paulo é assertivo e não mostra questionamento em relação aos passos que dá ou aos que dera no passado. Tal formato, que é reforçado pela presença de um interlocutor - um neto ou neta -, se apresenta como uma estratégia interessante, uma vez que faz com que o narrador apresente a sua versão dos fatos numa forma de diálogo, possibilitando que se associe esta figura ao mundo exterior à narrativa.

Ele, que é seguidor das regras e obediente às instituições governamentais, vê no posicionamento e nas escolhas do irmão mais novo o afastamento da vida ideal, organizada pelo trabalho, pela construção de uma família, ou seja, uma vida em que, diferentemente da sua, não se seguem padrões normativos. Para Zé Paulo, o caçula era "um moleque mimado, não gostava de ir pra escola, não gostava de fazer o serviço da casa (NAKASATO, 2017, p. 50)”. A série de desaprovações em relação ao irmão mais novo, destacada em palavras como moleque, preguiçoso, vagabundo, permeia a narrativa do primogênito. Zé Eduardo é visto como um menino que fora de certa forma, duplamente superprotegido pela mãe e pela única irmã mulher, Maria Luísa. Desta maneira, Zé Paulo observa que Zé Eduardo gozou de cuidados e privilégios que não foram garantidos a nenhum dos outros três irmãos. Ele é, por exemplo, o único dos quatro irmãos que tem acesso ao ensino superior. Zé Eduardo escolhe estudar Economia, avaliado por Zé Paulo como um "curso que não servia pra nada" (NAKASATO, 2017, p. 51). Pela não conclusão do curso, o primogênito narra:

[...] a gente não pôde estudar, a gente tinha que trabalhar, e ele era o caçula, então teve a chance, teve a chance e desperdiçou. Essa coisa da gente já nascer preguiçoso ou trabalhador, ou gostar de estudar, acho que Zé Eduardo já nasceu assim, preguiçoso, Maria Luísa e a mamãe só deram um empurrãozinho. (NAKASATO, 2017, p. 51)

Há, então, diferentes formas de compreender o ressentimento de Zé Paulo em relação a Zé Eduardo. São tratamentos dessemelhantes recebidos na infância, assomados de vivências, também díspares, que lançam olhares particulares para as possibilidades futuras. Se na infância não eram parecidos, os caminhos divergentes tomados por cada um os afastam ainda mais. $\mathrm{O}$ sentimento de responsabilidade e o dever que Zé Paulo sente para a manutenção do bem-estar dos pais em Maringá é ausente em Zé Eduardo. No seu ponto de vista, o erro do irmão é não priorizar a sua família nem mesmo o trabalho, como ele mesmo afirma: "Zé Eduardo largou a mãe chorando para se aventurar lá com aqueles desordeiros" (NAKASATO, 2017, p. 27). Na aliança do irmão com os movimentos revolucionários, ademais de um ponto de vista politicamente discordante, ele vê desprendimento daquilo que considera ser o correto, a maneira digna e certa de se viver. 
Em Dois, Zé Paulo assume uma posição política de não enfrentamento às repressões do regime ditatorial: "Para mim, eles eram desordeiros" (NAKASATO, 2017, p. 83). Desordeiros é a denominação repetida por Zé Paulo em várias passagens para descrever o grupo ao qual o irmão mais novo se filiava politicamente. Para ele, que "sempre foi pela ordem, aquela ordem que está escrito na nossa bandeira, se tem governo, tem que ser respeitado, caso contrário vira bagunça” (NAKASATO, 2017, p. 83), não há distinção entre um governo democrático e o estado de exceção que se alastrou sobre o país no período da ditadura. O governo que está no poder existe a fim de dar a ordem necessária para que o cotidiano das pessoas transcorra de maneira normal. Cabe, então, às pessoas dançarem conforme a música que os líderes tocam. Um aparelho governamental como o militar, que prima pelo cumprimento de diretrizes claras e retas, similares às verdades de Zé Paulo, parece corroborar a sua antipatia aos movimentos que se opunham à vigência de tal sistema. É importante ressaltar, no entanto, que Zé Paulo não se põe ao longo da narrativa nem contra nem a favor do regime militar. Na noção dele, a junta militar está no poder e cabe aos seus organizadores a palavra final nas decisões. Da mesma forma, Zé Paulo, assim como os brasileiros, uma vez que posicionados dentro desta relação de poder, devem obedecer às ordens que lhe são impostas.

A noção da posição de Zé Paulo, que é afastada e não-crítica às práticas ditatoriais, parece indicar um cenário que convida ao não-envolvimento em tais questões. Luciana Hidalgo (2020), em "Rio-Paris-Rio e o autoritarismo nos corpos, nos afetos, na genealogia: o que uma ficção sobre o golpe de 1964 tem a dizer sobre o golpe de 2016", apresenta uma percepção similar. No texto, Hidalgo reflete sobre a sua própria infância. Ela pondera que a atravessou "sem perceber os efeitos da ditadura incidindo sobre as rotinas, os corpos, os afetos que me rodeavam". Hidalgo (2020, p. 174) reforça o ambiente de alienação que se instaurou, ao dizer que "o que se criou nesse período foi uma população amedrontada e alienada, que evitava se politizar, ou ler, ou se informar". Tal atmosfera apontada por Hidalgo (2020) é também observada em Dois através do que narra Zé Paulo. Nem mesmo a inclusão do irmão nos movimentos contra a repressão é capaz de mostrar-lhe uma nova perspectiva.

O irmão mais novo, Zé Eduardo, já participava de movimentos estudantis ainda na adolescência, previamente à sua ligação à ALN. Nota-se, em Zé Paulo, a reprovação das escolhas do irmão caçula. Em dado episódio, Zé Eduardo recebe na casa dos pais o companheiro de militância Antônio dos Três Reis para "participar de uma reunião da União Maringaense de Estudantes” (NAKASATO, 2017, p. 83). A presença do companheiro desperta a desconfiança em Zé Paulo pois “o Três Reis já era universitário, ele vinha lá de Apucarana, para se meter no 
meio da molecada, pra falar mal do governo" (NAKASATO, 2017, p. 83). Em primeiro lugar, há a não-aprovação pela diferença de idade entre os dois. Pode-se pensar que ele não esperava que Três Reis, já universitário, estivesse envolvido em discussões políticas com adolescentes, como o irmão. Antônio dos Três Reis, que à época cursava a universidade, deveria ter deixado de lado as questões políticas, que Zé Paulo pensa supérfluas, insignificantes, vide a sua posição de não enfrentamento. De certa maneira, ele nota a subversão do seu entendimento do espaço universitário como um lugar de profissionalização, de iniciação no mundo do trabalho. Em segundo lugar, está a própria rejeição à visão política do irmão mais novo e do amigo. Observase no trecho a seguir:

Quando eu cheguei lá com a sua avó, os dois estavam na sala falando sobre a Revolução de 1964, sobre a ditadura militar, sobre censura, aquela conversa de comuna. Eu chamei meu pai num canto, falei pra ele, Olha, pai, não é certo esses dois aí, na sua casa, falando mal do exército, falando que vão derrubar o governo, mas o seu bisavô não se incomodava. (NAKASATO, 2017, p. 83)

O sentimento de antipatia de Zé Paulo para com os movimentos que se punham contrários à repressão é atestado pelas narrativas que são consideradas oficiais. A exemplo disso, pode-se levar em consideração o que noticiários na época reportavam. Há dois momentos interessantes que exemplificam diferentes noções sobre acontecimentos e como tais eventos foram explicitados pela mídia. O primeiro deles mostra uma contraposição de ideias da irmã dos dois narradores, Maria Luísa, e o próprio Zé Paulo. Logo após a saída de Zé Eduardo de Maringá, cidade natal da família, Zé Paulo confirma suas suposições sobre o destino do irmão dizendo que o irmão mais novo "entrou para um daqueles grupos de baderneiros, que roubavam bancos, que sequestravam, que matavam gente inocente" (NAKASATO, 2017, p. 85). Maria Luísa, que em vários momentos se constitui como a voz apaziguadora dos enfrentamentos entre os dois Josés, tenta contrapor o ponto de vista do irmão mais velho ao que ele então narra:

[...] ela tentando defender o irmãozinho, falando de democracia, sobre defender os mais pobres, mas eu acompanhava os noticiários, sabia tudo o que estava acontecendo, aquele bando de comunistas, querendo transformar o Brasil numa Cuba. Maria Luísa dizia que eu não devia acreditar no que os noticiários diziam, mas eu não era nenhum ignorante, o que eu sabia é que tinha um governo e um bando de desocupados que não deixavam o governo governar. (NAKASATO, 2017, p. 85)

$\mathrm{O}$ choque das narrativas midiáticas oficiais com as narrativas dos que formavam a guerrilha anti repressão também se apresenta numa das passagens narradas por Zé Eduardo. Durante uma partida de futebol entre Santos e Corinthians, Zé Eduardo, que estava acompanhado do companheiro de guerrilha Eriberto, escuta o locutor da partida anunciar que "foi morto pela polícia o líder terrorista Carlos Marighella" (NAKASATO, 2017, p. 109), ao 
que os dois, atônitos pela perda do líder, foram obrigados a escutar os aplausos de ambas as torcidas:

Naquele momento, não sei se me feriu mais a notícia da morte de Marighella ou se a
alegria da multidão. Os aplausos e outras manifestações verbais mais efusivas nos
ilharam numa muda perplexidade. Quando deixamos o estádio ainda pudemos ouvir
um torcedor gritar: - Terrorista filho da puta! Já vai tarde! (NAKASATO, 2017, p.
109)

As informações conflituosas sobre os acontecimentos permeiam o avanço da narrativa da mesma maneira que se espalhavam pelo cenário brasileiro na ditadura. Percebe-se como estavam dadas as questões ideológicas no momento. Não obstante a apresentação de Marighella como um líder terrorista, há também a sensação de cooperação da população pelas manifestações observadas no estádio. Observa-se um ciclo de afirmações sobre o funcionamento do aparelho ditatorial no país. Se de um lado há uma imprensa que promove uma narrativa sobre a ditadura, há, do outro, a população que conhece as práticas do sistema através do que é apresentado pelos próprios meios de comunicação. Deste modo, há a criação de uma narrativa que se torna oficial e que é reproduzida consistentemente. É, inclusive, a narrativa a qual Zé Paulo se afilia e reproduz.

Pelo episódio do jogo, é importante notar que o que está demonstrado é a contraposição da narrativa do próprio sistema ditatorial, ou seja, o líder terrorista Marighella, e da narrativa daqueles que lutam contra o sistema, companheiros de Marighella. Sobre as informações que chegavam à população no período, Hidalgo (2020, p. 173) escreve que a "televisão [...] era praticamente estatal em termos de ideologia". Marialva Barbosa (2014), professora e pesquisadora na área de história e imprensa, escreve que, sob o argumento estatal de que se vivia um período de guerra, informações que se opunham ao regime eram constantemente alijadas das páginas dos jornais. Os meios de comunicação, então, sob olhar cauteloso de censores, "além de informar, deveriam orientar a população, tutelados pelo estado" (BARBOSA, 2014, p. 15). É de suma importância salientar o ponto de orientação trazido por Barbosa (2014). Pode-se observar que a presença de censores dentro das instituições de comunicação identifica que o aparelho ditatorial se utilizava dos diferentes meios midiáticos para construir uma espécie de amparo ideológico. Uma vez que havia grupos que se opunham ao funcionamento do governo militar, era necessário que a população fosse constantemente relembrada do ponto de vista ideológico do estado: havia um perigo pairando sobre a sociedade brasileira e o estado militarista estava presente para blindar a população de tal ameaça. O que se segue em Dois, sobre a morte de Carlos Marighella, mostra a recepção da mesma notícia 
pelo outro ponto de vista, isto é, a perspectiva daqueles que estavam atrelados às organizações de resistência. Constata-se a revolta de Zé Eduardo ao saber dos informes jornalísticos sobre o acontecimento. A versão de que os seguranças pessoais do líder haviam dado início ao tiroteio é refutada:

As matérias jornalísticas noticiavam que ele reagira a uma ordem de prisão de agentes da Operação Bandeirante na alameda Casa Branca, no Jardim Paulista, e que os homens que realizavam a segurança de Marighella começaram a disparar, dando início a um tiroteio, em meio ao qual ele fora baleado. Mentira. A versão da polícia foi divulgada pela imprensa e ganhou status de verdade, mas não havia homens de segurança, não houve reação. Marighella foi executado à queima-roupa. (NAKASATO, 2017, p. 109)

As constantes tensões às quais a imprensa foi submetida durante o regime militar resultou em uma produção que identificava somente um dos lados da história como o lado correto. A disseminação de informações que se opunham às retratadas pela mídia oficial, sob o olhar cauteloso da censura, era esparsa e circulava de maneira clandestina. Barbosa (2014, p. 19) escreve que, nos meios oficiais de comunicação, "houve comprometimentos, jogos de acomodação, em uma palavra, constrangimentos nas ações dos jornalistas frente a um período de completa falta de liberdade".

Para Zé Paulo, para quem o governo do país existe justamente para reafirmar estas normas, a produção de informações que corroboram o seu pensamento não o faz pensar em realidades diferentes da sua. Em uma situação de repressão experienciada por Zé Eduardo em sua participação no movimento estudantil, ainda na adolescência, quando ele e os colegas do grêmio estudantil, como narra Zé Paulo, "faziam aqueles jornaizinhos" (NAKASATO, 2017, p. 84), a proibição da circulação do jornal pelo diretor da escola não é vista como problema. O que é repreendido pelo irmão mais velho é o fato de o pai ter sido chamado na escola "para ouvir um sermão que ele não merecia ouvir" (NAKASATO, 2017, p. 84). Para Zé Paulo, não é válida a tentativa do irmão mais novo de se opor ao regime vigente.

A desestabilização do que Zé Paulo conhece como ordem é causa da ojeriza que ele experiencia pelas vivências de Zé Eduardo. O choque das diferentes personalidades, o modo distinto de encarar a vida, desde a infância, são questões que provocam pequenos embaraços e atritos entre os irmãos. De comportamentos do irmão mais novo, interpretados como egoístas pelo primogênito - desobediência às ordens do irmão mais velho, a negação da ajuda em tarefas domésticas, até o enfim afastamento da família para se juntar à guerrilha urbana -, a visão de Zé Paulo sobre o irmão se constitui de pequenas rupturas de caráter que, ao longo dos anos, quebram pouco a pouco a relação dos dois. Na velhice, eles apenas identificam um no outro a 
relação sanguínea. A longa experiência compartilhada de estranhamentos sob o mesmo teto, somada à grande narrativa oficial sobre a Ditadura Civil-Militar, resulta na impossibilidade de que Zé Paulo compreenda as escolhas de Zé Eduardo. Sua oposição ao regime acaba afastando ainda mais os dois irmãos que, vivendo ou não sob o mesmo teto, habitando ou não a mesma cidade, se tornam meros conhecidos.

\section{2 "Perigoso é ver o trem da história passar"}

Zé Eduardo foi participante ativo dos movimentos contra a repressão no período. Ainda adolescente, após o golpe de 64, ele inicia sua participação política em movimentos estudantis na sua cidade natal, Maringá, e posteriormente atua de maneira mais ativa em ações contra a ditadura ao unir-se à Aliança Libertadora Nacional (ALN). Pela produção de cartoons e charges nos jornais da organização, ele torna-se procurado pelo regime e, por indicação da própria ALN, temendo uma represália violenta, ele exila-se. Primeiramente, ele vivencia o exílio no Chile, até a queda do governo de Allende em 1973. Após o trágico evento, ele parte para a França, país onde acaba vivendo a maior parte do exílio.

É na forma de narrar que está uma das maiores diferenças entre os irmãos em Dois. Enquanto Zé Paulo é absolutamente certo sobre sua caminhada, Zé Eduardo se apresenta como alguém que já não aposta no seu modo de ver a vida como único possível. Sua narrativa se constitui de uma análise da sua vida. Ele se coloca criticamente diante de escolhas e decisões que fez ao longo de sua trajetória. Em suas lembranças, similarmente ao irmão, estão expostas situações vividas na infância, na adolescência e juventude. Além disso, expõe-se sua participação como membro ativo de organizações contra a repressão do período ditatorial, culminando no seu tempo de exílio. Evidencia-se no irmão mais novo uma constante procura pela compreensão de si próprio e do outro, características suprimidas na narrativa do primogênito. $\mathrm{O}$ contraste se revela desde a primeira passagem em que o irmão mais novo assume a voz narrativa. Ele narra:

Hoje quase nada sei. Acordo todos os dias para viver as incertezas que me cabem, feliz por poder responder: eu não sei. A ignorância é leve, poupa-nos de muitos aborrecimentos. E o dia é longo, sinuoso. Embora os outros me assistam vivendo o concreto. (NAKASATO, 2017, p. 29)

A afirmativa das incertezas, sobre a sinuosidade dos dias, conversa diretamente com o que o próprio Zé Eduardo fala do pai. Como apontado na seção anterior, o pai era "um homem reto, traçou estradas retas para os filhos percorrerem" (NAKASATO, 2017, p. 47). Ao mesmo tempo que os caminhos retos foram percorridos por Zé Paulo, são deles, das estradas sem 
curvas, que Zé Eduardo procura se afastar. Enquanto o irmão tinha sido lançado ao mundo com “o peso da progenitura” (NAKASATO, 2017, p. 67), ele vê que a condição de caçula lhe deu "a inaptidão para as coisas sérias e me [lhe] conduziu a uma vida sem muitas regras, com poucos compromissos na agenda e uma estrada curva" (NAKASATO, 2017, p 67). É interessante observar a análise que o narrador faz sobre a própria trajetória. As incertezas, bem-vindas para o narrador no presente, contrastam com o adolescente que fora. Ele narra que "há mais de 40 anos, eu tinha certezas, e eram absolutas as certezas" (NAKSATO, 2017, p. 87). Pode-se entender que, para ele, a participação em movimentos contra a repressão da Ditadura CivilMilitar se mostrava urgente na juventude. A certeza da existência de algo a ser combatido se apresentava como um horizonte para que ele escapasse do caminho reto que lhe fora predestinado pelo pai. O envolvimento com as questões políticas e a luta pela liberdade de expressão o moveram a um outro rumo, distante da vida pacata e familiar na cidade natal.

Ainda na adolescência, Zé Eduardo dá os primeiros passos na sua caminhada junto ao movimento estudantil que se opunha à ditadura. A trajetória do personagem é composta de alguns estágios temporais que o levam a participar cada vez mais ativamente desta faceta da vida política. Primeiramente, Zé Eduardo aparece compondo o grêmio estudantil, assim como movimentos estudantis extraescolares. O ingresso na universidade aumenta o seu contato com estas organizações e o desencantamento com o curso de economia reverbera numa reflexão sobre suas prioridades no momento histórico:

Me recusava a percorrer a estrada reta que nosso pai traçara para mim: concluir o curso de economia, empregar-me em algum escritório, abrir, no futuro, um negócio próprio, qualquer negócio, talvez com a sua ajuda financeira. Teimei contra. Não tinha a intenção de seguir com o curso de ciências econômicas, que se tornara enfadonho, um peso. (NAKASATO, 2017, p. 102)

Descontente com os rumos que sua vida tomara, Zé Eduardo é constantemente convocado pelos apelos de companheiros para tornar-se um participante mais ativo na luta contra a repressão. Esta, parte constituinte da sua formação, esteve presente de forma mais ou menos escancarada ao longo de sua vida. O episódio da proibição da circulação do jornal produzido pelos membros do grêmio estudantil é um exemplo da infiltração desta prática do regime em diferentes instâncias sociais. Esta constante interpelação a qual Zé Eduardo é submetido, somada à insatisfação outorgada pela rotina em sua cidade natal, e pelas possibilidades pré-estabelecidas pelo caminho reto que era objetivado pelo pai, o conduzem à cidade de São Paulo. Para a família, "procurar um emprego, procurar um curso de desenho" (NAKASATO, 2017, p. 103) é a sua justificativa. No entanto, ele embarca em uma viagem sem 
data de retorno, com o objetivo clandestino de se "integrar à guerrilha urbana" (NAKASATO, 2017, p. 103).

A jornada de Zé Eduardo é dividida em dois momentos significativos: sua estadia em São Paulo como membro ativo da ALN e seu tempo no exílio. Sua chegada à capital paulista é marcada pela aura de desconfiança que se instaura. A namorada de Eriberto, companheiro já antigo que lhe oferecera moradia em São Paulo, é descrita como uma mulher que "olhava o tempo todo para os lados, desconfiada" (NAKASATO, 2017, p. 105), além de questionar a convicção de Zé Eduardo. A sensação de não confiança também é trazida à tona pelo diretor do jornal da ALN que pede que se "desconfie de todo mundo" (NAKASATO, 2017, p. 106). Similarmente à maneira que oculta a participação na guerrilha armada da família, entrar de fato no movimento, é uma extensão do mesmo ambiente. Todas as ações da organização devem ser meticulosamente calculadas para que não se cruze a linha entre o confiável e o não confiável, para que informações confidenciais não caiam na mão dos militares. A instauração de uma cultura do medo, torna-se marca do regime. Informações vazadas, levariam a sequestros, prisões e torturas. Segundo Enrique Serra Padrós e Jorge Eduardo Enriquez Vivar (2013, p. 28), o que se apresenta é a:

[...] criação de um novo modelo social construído a partir de uma política de terror exercida desde o Estado e de uma cultura de medo projetada sobre o conjunto da sociedade, procurando atingir até os comportamentos mais cotidianos de convivência. As estratégias para tanto fizeram parte de um plano sistemático e bem organizado de violação política, física, psicológica, massiva e sistemática dos direitos humanos.

Temer a tudo e a todos vira parte da rotina da população brasileira, sobretudo daqueles, ditos subversivos, que lutavam contra a perda de direitos. Uma cultura do medo aplicada àqueles a quem o estado deveria, na verdade, defender. $\mathrm{O}$ modelo repressivo agia "a partir de uma lógica de uso ostensivo, extensivo e intensivo de medidas repressivas, atropelando os limites constitucionais democraticamente estabelecidos sem sofrer controle ou restrição de nenhuma instituição que ainda responda, de alguma forma, à sociedade civil” (PADRÓS; VIVAR, 2013, p. 29).

Nesta atmosfera de desconfiança e medo é que Zé Eduardo se estabelece em São Paulo. Seu primeiro trabalho junto à ALN era "fazer charges para o jornal clandestino" (NAKASATO, 2017, p. 106) e "auxiliar na distribuição dos periódicos, o que não era tarefa tão fácil quanto parecia a princípio, pois, se a polícia me flagrasse distribuindo os jornais, seria imediatamente preso" (NAKASATO, 2017, p. 106). Contrapondo o que era apresentado nas mídias oficiais, 
por conivência ou pelo cerceamento dos órgãos de censura, o jornal da organização procurava apresentar as informações que não se expunham normalmente.

Além das atividades no periódico, Zé Eduardo participava das atividades de preparação para a guerrilha. Todas as tardes, acompanhado por Eriberto e mais companheiros, ele ia "a um barracão abandonado, em Santo Amaro, que servia como uma academia de treinamento" (NAKASATO, 2017, p. 106), onde todos eram submetidos a diversos tipos de exercícios físicos e praticavam técnicas de ataque, de defesa pessoal, uso de armas, preparação de bombas, entre outras atividades, a fim de se preparar para ações de combate iminentes. Em novembro de 1969 ele participa pela primeira vez na luta armada, seguida de duas outras ações, marcadas por falhas de Zé Eduardo:

Depois da segunda falha, ficou decidido que eu deveria ficar somente na gráfica clandestina do movimento, o que equivalia a dizer que eu não tinha estabilidade emocional para participar de uma ação armada. Senti-me humilhado, insisti para seguir realizando os treinamentos com armas, mas a direção não permitiu. (NAKASATO, 2017, p. 110)

O episódio sinaliza a sensação de impotência do personagem. Impedido de continuar nas ações armadas, ele devota seu tempo à produção das charges, que, no tempo da narrativa, “já haviam se tornado famosas entre os amigos e os inimigos" (NAKASATO, 2017, p. 110). Mais uma vez, percebe-se a vigia constante das forças militares. É pela notoriedade da sua produção artística que, após a invasão à gráfica, Zé Eduardo se torna procurado pelo regime:

Em maio de 1970, a gráfica foi descoberta e invadida. Eu não estava lá naquele dia. Os policiais perguntaram por mim, "aquele desenhador de merda", fizeram a minha descrição física. [...] tive certeza de que me tornara alvo da ditadura. A direção da ALN também compreendeu essa situação e providenciou minha fuga de carro para o Chile por uma rota que incluía Uruguai e Argentina. (NAKASATO, 2017, p. 111)

O exílio marca a desestabilização de Zé Eduardo, que não queria ter saído do Brasil. Ele deixa o país sem ter se despedido da família, que não via desde a partida de Maringá (NAKASATO, 2013, p. 113). Edward Said (2003, p. 50) estabelece o exílio como uma "solidão vivida fora do grupo: a privação sentida por não estar com os outros na habitação comunal”. A habitação comunal aqui, para Zé Eduardo, é seu país de origem, lugar onde poderia estar junto de sua família, seus companheiros de ALN, ou seja, o seu povo. O "sentimento de desterro" (NAKASATO, 2017, p. 113) experienciado por ele se agrava quando, já no Chile, ele descobre que a ditadura decretara que ele não poderia mais voltar ao país (NAKASATO, 2017, p. 113). Um novo sentimento de impotência se apresenta, uma vez que Zé Eduardo parece não ter gerência sobre o próprio destino. O exílio vem como um conselho, e de certa forma uma imposição da ALN. No entanto, é importante frisar que ele se exila pois é procurado pelos 
agentes do sistema repressivo. Ainda que o exílio implique em situações adversas, Zé Eduardo não sai do país por escolha. Ele deixa o Brasil, pois é marcado como foragido pela própria nação.

O tempo no fora do Brasil serve de reflexão à personagem sobre a tomada de decisão em relação ao exílio. Zé Eduardo, que queria estar no seu país, ao lado dos seus companheiros (NAKASATO, 2017, 113), reflete sobre uma das bases da ALN, a primazia do coletivo sobre o indivíduo, e o atormenta a ideia de que fora exilado não necessariamente por sua própria segurança, mas pela do grupo. Ele, que se encontra em completo estado de desterro, precisa lidar ainda com a angústia de não se sentir parte do próprio grupo, de não ter o amparo do companheirismo que acreditava ter na organização.

Contudo, são os anos passados em terras longínquas, os novos companheiros que encontra, que lhe ensinam lições valiosas sobre isso. É importante que não se veja a expatriação como algo benéfico, como um tempo de ponderações positivas. As reflexões podem ou não acontecer ao longo de qualquer momento - na ou fora da condição de exilado. Como narra Zé Eduardo, “os anos na França me ensinaram: paciência, a tranquilidade proporcionada pela ignorância e a alegria advinda da verdade que não se encontra em livros e nas palestras acadêmicas (NAKASATO, 2017, p. 117). Os anos ensinaram tais lições. Os horrores do exílio não. Zé Eduardo resiste a este robusto fardo, mas ele não lhe deixa livre de arranhões e de traumas. Zé Eduardo foi privado da segurança de viver na sua casa, no seu país. Foi privado de fazer as suas escolhas e de comandar o próprio destino. Aprende, muda, cresce, pois os anos passam. Não porque o exílio ensina, mas, sim, tira.

Quando a anistia do governo possibilitou o meu retorno ao Brasil em 1979, já não era mais o jovem inquieto que deixou a casa dos pais para entrar na guerrilha. Meus passos estavam mais vagarosos, aprendi a desfrutar o caminho, a buscar o sentido do presente. (NAKASATO, 2017, p. 118)

Em 1979, o personagem de Dois, Zé Eduardo, que fora proibido de retornar ao Brasil, é agraciado pela Lei de Anistia e volta, depois de quase dez anos de exílio, entre Chile, pequenas passagens no Uruguai e na Argentina e um longo período na França. A lei que permitiu a volta de Zé Eduardo ao Brasil é a que também apaziguou a repressão, a censura, a tortura, a violência os desaparecimentos e tantas outras práticas do governo militar. Maria Rita Kehl (2010), em "Tortura e o Sintoma Social”, observa que "o Brasil foi o único país da América Latina que "perdoou" os militares sem exigir da parte deles nem reconhecimento dos crimes cometidos nem pedido de perdão" (2010, p. 124). A autora, que neste artigo conversa sobre a normalização de atos de tortura na sociedade brasileira, pensa que há ainda muitos resquícios dos tempos de 
regime militar no presente do Brasil. Diferentemente de outras nações do Cone Sul que organizaram debates públicos e julgamentos dos algozes da ditadura, o processo de anistia no Brasil introduz uma abertura política que silencia os horrores vividos e perdoa àqueles que estiveram envolvidos de maneira ativa com movimentos a favor ou contra a ditadura.

Zé Eduardo volta perdoado pelos seus crimes. Paradoxalmente, perdoado pela sua resistência e pela luta contra o regime militar, contra a opressão. Ele volta roubado de quase uma década de vida no seu país natal. Zé Eduardo retorna ao Brasil e "já não era mais aquele jovem que deixou a casa dos pais para entrar na guerrilha" (NAKASATO, 2017, 118). O governo brasileiro começa a dar os primeiros passos rumo ao término do regime militar, que se estende ainda até 1985, mas que em 1979 permite retorno aos exilados, iniciando o vagaroso processo de abertura política.

O mesmo processo de abertura política é tema de "Autoritarismo e Transição", por Paulo Sérgio Pinheiro (1991). O autor evidencia que o momento imediato da abertura promove uma sensação de melhoria na realidade do país, pois "as liberdades políticas são restauradas, eleições são convocadas, a alternância no poder volta” (PINHEIRO, 1991, p. 46). Ou seja, a maneira como o sistema da ditadura estava posto perde a sua estrutura, mostrando uma renovação, uma mudança à população, principalmente àqueles diretamente atingidos pelas consequências da repressão empregada no período. É a partir do mesmo processo que Zé Eduardo volta a sua terra-mãe. No entanto, a reorganização política que ocorre após o regime, herda costumes, práticas e possibilidades de sua irmã mais velha, ou seja, "a democracia não está garantida" (PINHEIRO, 1991, p. 46). Os rastros deixados por anos de regime permanecem ativos e autorizados, pois estavam sob a tutela de uma suposta neutralidade:

Os funcionários do estado que praticaram a tortura, ou aqueles que serviam à repressão ilegal (por exemplo, médicos legistas que deram laudos falsos, delegados encarregados de providenciar o recolhimento de corpos de dissidentes políticos assassinados) continuam em função graças à anistia política. (PINHEIRO, 1991, p. 50)

Pinheiro (1991) aponta para a manutenção da característica autoritária na transição política da década de 1980. Em um país com um histórico de impunidade com seus crimes, não é de se espantar que a Lei de Anistia surja como mecanismo de troca de poder, perdoando os algozes do regime. Ainda que a publicação do artigo de Pinheiro date de 1991, Kehl aponta para a mesma permanência de tais resquícios vinte anos mais tarde, ou seja, apesar dos anos que separam as duas escritas, o panorama ainda se assemelha. Segundo a autora, 
autocráticos, e que sob um regime democrático não precisamos mais nos ocupar daqueles deslizes do passado. (KEHL, 2010, p. 128)

A análise de Maria Rita Kehl fala sobre a esfera de autorização da tortura no presente do país - tortura essa que se assemelha àquela aplicada por representantes do estado brasileiro no período da ditadura. Assim, é importante chamar a atenção para este sintoma apontado por ela como parte de um grupo de outros sintomas que eram práticas do governo dos militares. Em outras palavras, a tortura ainda é aceita como "mal necessário" (KEHL, 2010), argumento que "parece convincente a grandes parcelas da população brasileira" (KEHL, 2010, p. 131), pois a própria ditadura é vista com bons olhos até hoje por uma parcela considerável da população brasileira que reivindica a volta do sistema e das práticas ditatoriais.

Desta forma, nota-se que o embate dos dois irmãos que é trazido por Nakasato em Dois é um cenário ainda recorrente no presente do país. A sensação nostálgica da ditadura apresentase na narrativa de Zé Paulo, o irmão mais velho. Mesmo que ele fale de memórias, suas falas não demonstram que haja na sua mente nenhum tipo de questionamento sobre a maneira como ele via a luta do irmão ou como havia crueldade das práticas repressivas. Para ele, tais ações não eram vistas como cruéis. Elas eram parte das manobras que deveriam existir para que os que se opunham às diretrizes governamentais andassem na linha do que lhes era imposto.

As narrativas de Dois expressam um Brasil do presente. Um Brasil que expõe diariamente uma tensão ideológica em relação à Ditadura Civil-Militar. Em "Falas da Tortura" (2010), James Ginzburg aponta o paradoxo nas práticas da população brasileira. Ele vê que, "no momento presente, no país, são ampliadas as discussões sobre os direitos humanos e se multiplicam os interesses na formação de grupos do excluídos” (GINZBURG, 2010, p. 135), ao mesmo tempo que, ao longo dos anos 1990, "o debate político e social tem dado mostras [...] de um interesse de parte da população pelo retorno de regimes autoritários, sob alegações referentes à falência da democracia, considerada uma bagunça fora de controle" (GINZBURG, 2010, p. 135). Zé Paulo é representante desta parcela do país que tem se sentido encorajada a contestar o ambiente democrático pós ditadura. A coragem é reforçada pela Lei da Anistia e pela forma que as ações repressivas eram expostas durante o período, o que impediu perceber questões fulcrais correntes durante o período militar: tortura, falta de liberdade, desaparecimentos, entre tantas outras formas de repressão. É necessário que se fomente cada vez mais no país um debate massivo expondo os horrores vividos por tantos Zé Eduardos. É necessário que esta outra narrativa, que não ganhou o status de oficial, esteja mais presente. É imprescindível que ela se contraponha à narrativa dos Zé Paulos que permite a rememoração e 
o sentimento nostálgico de ações que ferem direitos humanos básicos, que diminuem o acesso à liberdade e que são, por constituição, ações antidemocráticas.

\section{Considerações finais}

A construção narrativa feita por Nakasato demonstra a tensão das vozes de Zé Eduardo e Zé Paulo, suas diferentes visões de mundo - desde âmbitos absolutamente íntimos e privados até a questões de análise social - de forma mais evidente no que diz respeito à ditadura. Estes irmãos, ainda que dificilmente em contato direto, pelo afastamento que se ergue ao longo dos anos, coabitam o mesmo cenário. Não seria a intenção de Nakasato mimetizar o espaço brasileiro? Não seriam os dois Josés, filhos de um mesmo José Pereira, irmãos de sangue, também irmãos, pois são filhos de uma mesma nação? Não seriam estes dois personagens demonstrações de inúmeras outras vozes que contrastam nos diversos cantos do Brasil?

Procurou-se discutir no artigo a construção feita por Nakasato destes dois irmãos, Zé Paulo e Zé Eduardo. Embora filhos de um José Pereira, que transfere para os filhos seus valores e suas crenças, os dois irmãos mostram-se bastante diferentes desde os primeiros passos que dão em Maringá e, consequentemente, na narrativa de Dois. Suas pulsões, seus desejos e seus objetivos são distintos, o que lhes confere vidas e modos de narrar, também, bastante singulares. Zé Eduardo quando traz suas memórias da participação nos movimentos anti repressão da ditadura, se mostra analítico e reflexivo. Por outro lado, Zé Paulo, que se põe contrário às escolhas do irmão, narra sua história a um interlocutor, um neto ou uma neta, e despeja suas reclamações, suas verdades, seus julgamentos e seus ressentimentos a cada palavra.

O momento que circunscreve Dois, sem a exposição de uma data específica, é o tempo contemporâneo. O tempo em que, mais de trinta anos após o processo de reabertura política no país, há uma ambivalência que paira o imaginário brasileiro sobre a Ditadura Civil-Militar, como apontado por Kehl (2010) e Ginzburg (2010).

Dois nos faz lembrar que falas como as dos dois irmãos existem e que ainda estão presentes no cenário atual. Zé Paulo e Zé Eduardo ainda caminham pelas ruas do mesmo Brasil. Eles ainda frequentam os mais diversos espaços: são empresários, artistas, professores, vendedores, aposentados, universitários, idosos, políticos, jornalistas, influencers, e tantas outras posições quanto possam ocupar. Seus discursos ainda repercutem pelos mais diversos espaços e podem normalizar ou problematizar o que ocorreu entre os anos de 1964 a 1985 . Num país cujo histórico de impunidade com os seus crimes atravessa os tempos, a literatura que relembra a ditadura, torna-se "elemento ativo na transmissão da memória para que não se 
apague aquilo que afetou a vida das pessoas" (FIGUEIREDO, 2017, p. 46). Que a literatura sirva como um lembrete de que os traumas do passado do Brasil, seja este recente ou longínquo, ainda estão latentes no nosso presente.

\section{Referências:}

BARBOSA, Marialva. Imprensa e ditadura: do esquecimento à lembrança em imagens sínteses. Revista Brasileira de História da Mídia (RBHM), v. 3, n.2, julho/2014.

FIGUEIREDO, Eurídice. A literatura como arquivo da ditadura brasileira. Rio de Janeiro: 7 Letras, 2017.

GINZBURG, Jaime. Escritas da Tortura. In: TELLES, Edson, SAFATLE, Vladimir (orgs.) $O$ que resta da ditadura: a exceção brasileira. São Paulo: Boitempo, 2010. p. 133-150.

GOMES, Gínia Maria. O Romance Brasileiro: as ruínas de um passado traumático. In: GOMES, Gínia Maria (org.) Narrativas Brasileiras Contemporâneas: memórias da repressão. Porto Alegre: Polifonia, 2020. p. 7-17.

HIDALGO, Luciana. Rio-Paris-Rio e o autoritarismo nos corpos, nos afetos, na genealogia: o que uma ficção sobre o golpe de 1964 tem a dizer sobre o golpe de 2016. In: OLIVEIRA, Rejane Pivetta de, THOMAZ, Paulo C. Literatura e Ditadura. Porto Alegre: Zouk, 2020. p. 173-179.

KEHL, Maria Rita. Tortura e Sintoma Social. In: TELLES, Edson, SAFATLE, Vladimir (orgs.). O que resta da ditadura: a exceção brasileira. São Paulo: Boitempo, 2010. p. 123-132.

NAKASATO, Oscar. Dois. São Paulo: Tordesilhas, 2017.

PADRÓS, Enrique Serra; VIVAR, Jorge Eduardo Enriquez (orgs.). Memórias da resistência e da solidariedade: o Movimento de Justiça e Direitos Humanos contra as ditaduras do Cone Sul e sua conexão repressiva. Porto Alegre: Ed. ASF-Brasil, 2013.

SAID, Edward. Reflexões sobre o exílio. In: SAID, Edward. Reflexões sobre o exílio e outros ensaios. Trad. Pedro Maria Soares. São Paulo: Companhia das Letras, 2003. p. 46-60.

TELLES, Edson, SAFATLE, Vladimir. Apresentação. In: TELLES, Edson, SAFATLE, Vladimir (orgs.). O que resta da ditadura: a exceção brasileira. São Paulo: Boitempo, 2010. p. 9-12. 